Agnieszka Chamera-Nowak

Warszawa

\title{
Problemy złej jakości wykonania książek w latach pięćdziesiątych XX wieku w Polsce: stalinowskie diagnozy, rzeczywiste przyczyny
}

Problem poprawienia szaty graficznej i wykonania ksiażek pojawiał w postulatach bibliotekarzy i księgarzy, w notatkach prasowych, w skargach nadsyłanych do wydawnictw oraz urzędów nadzorujących rynek wydawniczy przez cały okres PRL. Szczególnie zła jakość (zarówno pod względem wykonania, jak i szaty graficznej) miały publikacje wydawane masowo na przełomie lat 40 . i 50 .

Najczęściej zwracano uwagę na brak: ładnych okładek z rycinami, kolorowych ilustracji, opraw ${ }^{1}$, a także na zły papier i jakość druku, zbyt małą czcionkę (np. petit), jednolitość formatów (tj. stosowanie głównie ósemki - zwłaszcza w odniesieniu do książek dla dzieci) ${ }^{2}$. Na łamach pisma branżowego „Poligrafika” wytykano błędy: ,zamazany tekst, wiersze przycięte przy oprawianiu, zbyt mała czcionka, karta udarta w połowie, okładka od-

\footnotetext{
${ }^{1}$ Większość ówczesnych książek posiadała tylko tzw. oprawy księgarskie, sprzyjające szybkiemu ich zniszczeniu. Publikacje, które trafiały do bibliotek, albo czekały na wykonanie opraw, albo były bardzo szybko wycofywane ze względu na ,zaczytanie”. Odsetek książek oprawnych wahał się w bibliotekach gminnych od 40 do 90 proc. Obowiązywała zasada oprawiania wyłącznie wydawnictw wielkoarkuszowych (w granicach ponad 15 arkuszy drukarskich) o trwałej wartości. AAN, Centralny Urząd Wydawnictw, Przemysłu Graficznego i Księgarstwa (dalej CUWPGiK), 379, s. 52, Wyciag z syntetycznego opracowania monografii gmin; tamże, 2, Protokół nr 36 z posiedzenia Prezydium Centralnego Urzędu Wydawnictw z 25 listopada 1952 r.; AAN, Centralny Zarząd Bibliotek (dalej: CZB), 97, k. nlb., P. Grochmalicki i J. Osikowski, Monografia stanu bibliotek i czytelnictwa w gminie Brzeźnica, powiat Dębica woj. rzeszowskiego, styczeń 1953.

${ }^{2}$ Zob. Ogólnopolski Zjazd Bibliotekarzy - Warszawa 16-18 lutego 1956 - Księga pamiatkowa, [red. Bogdan Horodyski], Warszawa 1957, s. 170, 303, 367; AAN, CUWPGiK, 379, s. 55, Wyciąg z syntetycznego...; tamże, 6, Sprawozdanie z przebiegu załatwiania skarg i zażaleń w CUWPGiK za okres od 1.01 do 31.03.1954 r.; tamże, Sprawozdanie z przebiegu załatwiania skarg i zażaleń w CUWPGiK za okres od 1.04 do 30.061954 r.; tamże, 12, k. nlb., Protokół nr 3 z posiedzenia Kolegium Urzędu z dnia 21 stycznia $1956 \mathrm{r}$.
} 
wrotnie wklejona, zła kolejność stron, strony niezadrukowane, druk podwójny, pomieszany tekst między stronami, brak wklejek, słabe szycie (puszcza), różna tonacja farby w jednym dziele”, ,ogromna ilość błędów w składzie, przestawianie wierszy, wadliwe justowanie, przebijanie farby, nierówne krycie, nieprawidłowe umieszczanie sygnatur grzbietowych $w$ arkuszach książek , [...] brak arkusza, arkusz z innej książki, arkusz lub okładka wklejona na opak”". Do wydawnictwa „Czytelnik”, zachęcającego odbiorców swoich publikacji do nadsyłania uwag o przeczytanych pozycjach (odnośnie tematu, treści, języka, wyglądu, błędów, oczekiwań i życzeń) w 1952 r. nadeszło ok. 300 listów, z których duża część dotyczyła braków w wykonaniu książek ${ }^{5}$.

W 1952 r. Jan Karolczak na łamach „Poligrafiki” tak wyjaśniał powody złej jakości książek: „Poziom jakości produkcji graficznej w kraju nie poszedł równolegle $\mathrm{z}$ rozbudową przemysłu poligraficznego $\mathrm{w}$ okresie powojennym i dotychczas nie został ustawiony odpowiednio do wymagań i potrzeb odbiorcy. Dotyczy to w szczególności jakości produkcji książek. [...] Stąd uwagi krytyczne kupujących książki zamieszczane w prasie, wskazujące usterki (...)"

Centralny Urząd Wydawnictw, Przemysłu Graficznego i Księgarstwa $(\mathrm{CUWPGiK})^{7}$ podzielał to zdanie - jako przyczynę wskazywał wadliwy i przestarzały system planowania produkcji poligraficznej i wydawniczej. Zlecał zatem cyklicznie opracowywanie nowych systemów planowania, co nie spowodowało radykalnej zmiany w podległych mu zakładach graficznych, borykających się z ogromnymi problemami natury materiałowej i technicznej oraz organizacyjnej. s. $1-2$.

${ }^{3}$ I. Łużnicki, O podniesienie jakości druku i oprawy ksiażki, „Poligrafika”, 1:1954,

${ }^{4}$ Leonard Szafrański, O jakości produkcji, „Poligrafika”, 2:1953, s. 6-7. Podaję za: Przeglą piśmiennictwa. Z zagadnień ksiażki i czytelnictwa w prasie, „Bibliotekarz”, 4:1955, s. 119-120; B. Gawin, W kalejdoskopie księgarskim, „Przegląd Kulturalny”, 8:1955, s. 248; Celestyn Kwiecień, O grafice ksiażkowej, „Życie Literackie”, 175:1955; Stanisław Ostrowski, Nie kupuj mnie, czytelniku, „Świat” 7:1955; J. Garztecki, A jednak szmira, „Przegląd Kulturalny:, 17:1955.

${ }^{5}$ Roman Tomaszewski, Jak Czytelnik podwyższa jakość swoich wydawnictw, „Poligrafika", 2:1953, s. 10.

${ }^{6}$ Jan Karolczak, Zagadnienia kontroli technicznej w przemyśle technicznym, „Poligrafika", 5:1952, s. 4.

${ }^{7}$ CUWPGiK został utworzony z połączenia Centralnej Komisji Wydawniczej i Centralnych Zarządów: Przemysłu Graficznego oraz Księgarstwa, w latach 1951-1956 sprawował nadzór nad całością ruchu wydawniczego w Polsce i miał na niego decydujący wpływ -Dekret z dnia 2 sierpnia 1951 r. o utworzeniu i zakresie działania Centralnego Urzędu Wydawnictw, Przemysłu Graficznego i Księgarstwa, Dziennik Ustaw (dalej Dz. U.) 1951, nr 41, poz. 309.

${ }^{8}$ AAN, Ministerstwo Kontroli Państwowej, 24/173, Oświadczenie dla Inspektora Ministerstwa Kontroli w sprawie nie wykorzystania zaplanowanych sum przez Sam. 
Zniszczenia wojenne zakładów poligraficznych oszacowano na $85 \%$ stanu przedwojennego9. W 1956 r. specjalna komisja oceniła stan parku maszyn poligraficznych ${ }^{10}$. Okazało się, że składa się on z urządzeń reprezentujących rozmaite modele, częściowo bardzo zużytych, o rodowodzie w większości sięgającym początków XX w. Maszyny były wprawdzie remontowane po 1946 roku, ale z dużymi trudnościami - ze względu na brak części zamiennych, które można było kupić jedynie za dewizy. Natomiast sprzęt z importu i reparacji wojennych ${ }^{11}$, zainstalowany w 1950 roku, wymagał już remontów ze względu na dużą eksploatację (w niektórych zakładach praca odbywała się na trzy zmiany). Lepiej wyglądał park maszyn introligatorskich, który pochodził z reparacji i importu, jednak i ten wymagał remontu. Wiceprezes CUWPGiK, Józef Zaremba, podczas posiedzenia sejmowej Komisji Oświaty, Nauki i Kultury w kwietniu 1956 r. stwierdził: „W latach 1949-1950 powstała legenda

Wydział Techniki w roku 1953. [28 lipiec 1954 r.]; AAN, CUWPGiK, 14, k. nlb., Uchwała nr 28 Kolegium Centralnego Urzędu Wydawnictw, Przemysłu Graficznego i Księgarstwa o zadaniach przemysłu poligraficznego na najbliższy okres 1953-1954 podjęta na posiedzeniu w dniu 6 października 1953 r. (Prot. nr 10); tamże, 5, Protokół nr 6 z posiedzenia Kolegium Centralnego Urzędu Wydawnictw, Przemysłu Graficznego i Księgarstwa z 23 lutego 1954 r. Pkt. 1 Zmiana metodologii planowania w przemyśle poligraficznym.

${ }^{9} \mathrm{~W}$,zniszczeniach wojennych” miała udział także Armia Czerwona, która do października 1945 r. wywiozła do ZSRR 21 kompletnych drukarni oraz 250 maszyn drukarskich, 85 ton czcionek, 262 różnego rodzaju urządzeń drukarskich z terenów tzw. Ziem Odzyskanych, jako zdobycze wojenne. Zob. Witold Stankiewicz, Stanisław Siekierski, Ksztaltowanie się polityki wydawniczej $w$ minionym trzydziestoleciu, „Rocznik Biblioteki Narodowej", 10:1974, s. 80; AAN, Ministerstwo Informacji i Propagandy (dalej: MIiP), 892. Protokół z kontroli gospodarki i rachunkowości w CZPZG od dnia 23 maja 1945 r. do 1 października 1946 r.

${ }^{10}$ W maju i w czerwcu 1956 r. w „Życiu Warszawy” oraz w „Sztandarze Młodych” ukazały się notatki dotyczące zakupionych za miliony złotych maszynach drukarskich, które nawet od 1949 r. stały w magazynach. Dla wyjaśnienia tych zarzutów powołano specjalną komisję, która uznała, że sprowadzenie części maszyn było wprawdzie błędem ówczesnych kierowników przemysłu i doradców fachowych, ale w zasadzie maszyny te w pełni wykorzystywano oraz, że ,,przytoczone przez gazety fakty posiadaja wiele braków i błędnych informacji”-AAN, CUWPGiK, 25, k. nlb., Sprawozdanie Komisji, powołanej przez Zarząd Główny Związku Zawodowego Pracowników Kultury i Centralny Urząd Wydawnictw, Przemysłu Graficznego i Księgarstwa, do zbadania słuszności zarzutów, postawionych kierownictwu przemysłu graficznego w artykułach: „Ludzie i Maszyny” (,Życie Warszawy”, nr 124 z dnia 25 maja 1956 r.) oraz „Szukajmy miliardów - 1500 zbędnych maszyn” (,Sztandar Młodych”, nr 134 z dnia 5 czerwca 1956) oraz oceny obecnego stanu maszyn. Zob. także: I.A., ***, „Poligrafika”, 4-5:1956, s. 1-4; Dariusz Jarosz, Dzieje ksiażki w Polsce 1944-1989. Wybór źródet, Warszawa 2010, s. 20; AAN, CUWPGiK, 25, k. nlb., Wyciagi z prasy.

${ }^{11}$ Po wojnie Polska dostała ponad tysiąc maszyn drukarskich z reparacji wojennych, ok. $25 \%$ z nich w 1956 r. nie była remontowana-AAN, CUWPGiK, 13, k. nlb., Protokół nr 18 z posiedzenia Kolegium Urzędu z dnia 1 czerwca 1956. 
o przeinwestowaniu przemysłu graficznego. W rzeczywistości maszyny drukarskie są przestarzałe, pochodzą z lat 1910-1930. [...] Obecnie drukarnie mają 45 proc. możliwości produkcyjnej. Każda akcja „błyskawica”, jak np. wydanie materiałów XX Zjazdu, odbywa się kosztem innych książek - przerwaniem ich drukowania"12. Na jednym z posiedzeń tej Komisji poseł Czesław Wycech zauważył, że „na Targach Poznańskich różnica między książką polską a zagraniczną była ogromna, wynikła ona ze złej bazy poligraficznej"'13.

$\mathrm{Na}$ szatę graficzną wpływ miało także słabe wyposażenie drukarni w materiał zecerski. Stosunkowo ubogo przedstawiał się asortyment antykwowych czcionek ręcznych. Do tego wiele zestawów czcionek było zdekompletowanych. „Nie ma pod dostatkiem nowych, a stare zapasy mocno pofragmentowane. Redaktor techniczny zmuszony jest do ograniczania się do 2-3 krojów, możliwie zbliżonych do kroju pism maszynowych, jakimi składane są książki"14.

W 1946 r. Centralnemu Zarządowi Państwowych Zakładów Graficznych podlegało $45 \%$ drukarń. Nad pozostałymi zaś pieczę miały różnego rodzaju instytucje, spółdzielnie, ministerstwa, stowarzyszenia i inne centralne zarządy przemysłów ${ }^{15}$. Nadzór organizacyjny nad drukarniami pracującymi na rzecz wydawnictw w ciagu sześciu powojennych lat sprawowały aż cztery ministerstwa: Ministerstwo Informacji i Propagandy, Ministerstwo Kultury i Sztuki, Ministerstwo Przemysłu i Handlu, Ministerstwo Przemysłu Lekkiego. Jednocześnie przemysł graficzny podlegał reorganizacjom ${ }^{16}$. W 1951 r. przejał go CUWPGiK ${ }^{17}$. Pozostałe drukarnie nadal podlegały

${ }^{12}$ AAN, Kancelaria Sejmu I kadencji (dalej: KS), 21, k. 263, Protokół 10 posiedzenia Komisji Oświaty, Nauki i Kultury [11 kwietnia 1956 r.].

13 AAN, KS, k. 729, Protokół 28 posiedzenia Komisji Oświaty, Nauki i Kultury [27 października 1956 r.].

${ }^{14}$ R. Tomaszewski, Jak Czytelnik podwyższa..., s. 8.

${ }^{15}$ Zob. Mieczysław Kafel, Baza techniczna produkcji czasopiśmienniczej i ksiażkowej w okresie dziesięciolecia 1944-1954, [Warszawa 1956], s. 82.

${ }_{16}$ Zob. Stanisław A. Kondek, Władza $i$ wydawcy. Polityczne uwarunkowania produkcji ksiażek w Polsce w latach 1944-1949, Warszawa 1993, s. 50; AAN, CUWPGiK, 108. Plan sześcioletni przemystu graficznego, czwarty rzut 1950-55. Wrzesień 1949; A. Wysocki, Organizacja przemystu graficznego, „Poligrafika” 1:1951, s. 37-39; A.W., Państwowy przemyst poligraficzny w Polsce Ludowej. (Szkic organizacyjny), „Poligrafika", 5:1954, s. 36-39.

${ }^{17}$ CUWPGiK poprzez Centralny Zarząd Przemysłu Graficznego bezpośrednio zarządzał 45 drukarniami państwowymi (Zakłady Graficzne i Wydawnicze „Dom Słowa Polskiego" podlegały bezpośrednio urzędowi) oraz nadzorował zakłady podległe poszczególnym ministrom, np. poczt, kolei, finansów, obrony narodowej, instytucjom państwowym i organizacjom społecznym, a także trzy fabryki farb graficznych, odlewnię czcionek i cztery warsztaty napraw maszyn drukarskich - Uchwała nr 578 Rady Ministrów z dnia 11 sierpnia 1951 r. w sprawie zakresu działania i tymczasowej struktury 
różnego rodzaju instytucjom: RSW „Ruch”, Ministerstwu Oświaty (Państwowe Zakłady Wydawnictw Szkolnych) oraz Ministerstwu Przemysłu Drobnego i Rzemiosła (niewielkie zakłady o charakterze rzemieślniczym). Istnienie kilku ośrodków dyspozycyjnych utrudniało jednolite planowanie, inwestowanie i zarządzanie przedsiębiorstwami graficznymi ${ }^{18}$. Sam CUWPGiK nie był w stanie sprawnie kierować 53 podległymi mu podmiotami z różnych branż - graficznej, maszynowej, chemicznej i metalowej $^{19}$. Centralny Zarząd Przemysłu Graficznego nie panował bowiem nad produkcją tych zakładów. Nie wiedział, gdzie jaki tytuł jest drukowany ${ }^{20}$. System zarządzania odgórnego wydawnictwami, w którym przydzielano im konkretne drukarnie, skutkował tym, że np. Państwowe Wydawnictwo Rolne i Leśne drukowało w 1954 r. w 22 drukarniach ${ }^{21}$.

Organizacja pracy i system planowania powodowały, że np. niektóre wydawnictwa w pierwszym kwartale 1954 r. skierowały do produkcji 5\% planu rocznego, a w trzecim - aż $75 \%^{22}$. Sporządzały one bowiem plan wydawniczy, zanim dowiedziały się, jakie otrzymają limity na papier, etaty, fundusze na honoraria i prace zlecone. W połowie roku oficyny musiały rezygnować z opublikowania niektórych tytułów i zmniejszać nakłady, co rzecz jasna wywoływało także perturbacje w drukarniach ${ }^{23}$. Z kolei cennik robót poligraficznych sprawiał, że drukarnie niechętnie przyjmowały do wykonania pozycje bardziej skomplikowane, wielobarwne itp., bez problemu zaś - tanie akcydensy i wielkonakładowe broszury ${ }^{24}$.

Robotnicy nie byli zainteresowani podnoszeniem swoich kwalifikacji ani wykonywaniem prac wymagających dużych umiejętności, np. składu matematycznego, chemicznego czy w językach obcych, bo nie miało to przełożenia na wyższe zarobki ${ }^{25}$. Obowiązujący od 1 stycznia 1950 r. ka-

organizacyjnej Centralnego Urzędu Wydawnictw, Przemysłu Graficznego i Księgarstwa, Monitor Polski, 1951, nr A-85, poz. 1165.

${ }^{18}$ AAN, CUWPGiK, 13, k. nlb., Sprawozdanie Komisji Resortowej w sprawie statutu organizacyjnego Centralnego Urzędu Wydawnictw, Przemysłu Graficznego i Księgarstwa.

${ }^{19}$ AAN, CUWPGiK, 4, k. nlb., Protokół nr 10 z posiedzenia Kolegium CUWPGiK z 6 października $1953 \mathrm{r}$.

${ }^{20}$ AAN, CUWPGiK, 8, k. nlb., Protokół nr 2 z Kolegium CUWPGiK z dnia 11 lutego $1955 \mathrm{r}$

${ }^{21}$ AAN, CUWPGiK, 7, k. nlb., Protokół nr 58 z Kolegium CUWPGiK z dnia 15 października $1954 \mathrm{r}$.

${ }^{22}$ AAN, CUWPGiK, 8, k. nlb.; Protokół nr 2 z Kolegium CUWPGiK z dnia 11 lutego $1955 \mathrm{r}$.

${ }^{23}$ Tamże, Protokół nr 7 z Kolegium CUWPGiK z 6 maja 1955 r.

${ }^{24}$ AAN, CUWPGiK, 7, Protokół nr 61 Kolegium CUWPGiK z 15 listopada 1954 r.

${ }^{25}$ Zob. Tadeusz Kowalak, O taryfikatorze kwalifikacyjnym, „Poligrafika”, 4:1954, s. 4 . 
talog norm i taryfikator robót dla przemysłu graficznego nie ujmował bowiem wszystkich procesów produkcyjnych, szczególnie tych, do których potrzebny był personel o profesjonalnym przygotowaniu, a zaszeregowanie osobiste robotników niewykwalifikowanych i wykwalifikowanych nie dawało gwarancji wyższych zarobków tym ostatnim ${ }^{26}$. Stąd brakowało wysoko wykwalifikowanych pracowników różnych działów, np. w drukarni Dom Słowa Polskiego pracowało 23 z przewidzianych 40 składaczy $^{27}$. Wacław Mosiężny tak podsumował w „Poligrafice” w 1952 r. problemy kadrowe: „My nie posiadamy starej inteligencji technicznej, jesteśmy przemysłem, którym kierują w 100 proc. wczorajsi robotnicy, którzy kilka lat temu stali przy kasztach w zecerni, linotypach czy maszynach drukarskich. Równocześnie musimy stwierdzić, że kierownicy naszych zakładów przeważnie nie mają pełnego zakresu wiadomości technicznych, a z drugiej strony za słaby jest pęd samokształceniowy"28. Dopiero w 1967 r. uruchomiono - najpierw wieczorowe, a rok później dzienne - studia poligraficzne na Wydziale Geodezji i Kartografii Politechniki Warszawskiej. Natomiast w 1958 r. w Zjednoczeniu Przemysłu Poligraficznego utworzono Centralne Laboratorium Poligraficzne ${ }^{29}$.

Drukarnie i wydawnictwa borykały się z chronicznym brakiem odpowiedniego papieru. Wprawdzie papiernie dostarczały wymagane ilości materiału, ale coraz gorszego gatunku ( $7 \%$ wyprodukowanego w ogóle papieru przeznaczano na produkcję książek) i do tego w nieodpowiednich formatach, niedopasowanych do maszyn drukarskich. Papiernie miały problem z produkcją na zamówienie przemysłu graficznego. Dostarczane przez nie gatunki papieru nie były dostosowane do druku wypukłego, płaskiego i wklęsłodrukowego, papier odbiegał od norm technologicznych w swojej strukturze i wyglądzie zewnętrznym, a w rezultacie każda partia papieru wymagała innych metod pracy poligraficznej w każdej technice

\footnotetext{
${ }^{26}$ AAN, CUWPGiK, 4, k. nlb., Protokół nr 12 z posiedzenia Kolegium CUWPGiK z 21 października $1953 \mathrm{r}$.

27 AAN, CUWPGiK, 8, k. nlb., Protokół nr 6 Kolegium CUWPGiK z dnia 12 i 19 kwietnia 1955.

${ }^{28}$ Wacław Mosiężny, Przemyst graficzny na tle wskazań VII Plenum KC PZPR, „Poligrafika" 4:1952, s. 4.

${ }_{29}$ Centralne Laboratorium Poligraficzne (CLP) w 1971 r. zostało połączone z Centralnym Laboratorium Farb Graficznych w Gdańsku oraz Centralnym Laboratorium Akcydensów i Opakowań w Łodzi. Z dniem 1 stycznia 1973 r. nastapiło przekształcenie CLP w Ośrodek Badawczo-Rozwojowy Przemysłu Poligraficznego w Warszawie, który jest jednostką prowadzącą badania oraz prace rozwojowe i wdrożeniowe, a także związaną z nimi działalność edukacyjną i wydawniczą dla potrzeb przemysłu poligraficznego. Centralny Ośrodek Badawczo-Rozwojowy Przemysłu Poligraficznego, O Ośrodku, http://www.cobrpp.com.pl/mod.php?str=firma [19.08.2014].
} 
druku. Brakowało m.in. papierów: o niskiej gramaturze (40-45 g/mkw) do druku słowników, informatorów i kalendarzy; wysokogatunkowych kartonów i brystoli, papierów kredowych i satyny do druku wielobarwnych wkładek, rycin i reprodukcji oraz kartonu galanteryjnego na wyklejki i okładki ${ }^{30}$.

Nadzór nad przemysłem papierniczym oraz zapasami papieru przejęło w grudniu 1944 r. Ministerstwo Informacji i Propagandy ${ }^{31}$, a następnie utworzony 1 marca 1945 r. Centralny Zarząd Przemysłu Papierniczego i Centralny Urząd Planowania ${ }^{32}$. Od grudnia 1944 r. za ukrywanie zapasów papieru lub jakikolwiek nim obrót rynkowy groziła kara śmierci ${ }^{33}$. Część zakładów papierniczych w czasie wojny celowo zniszczył okupant niemiecki, część została przez niego zdemontowana i wywieziona, a część - zwłaszcza z tzw. Ziem Odzyskanych - Armia Czerwona potraktowała jako mienie zdobyczne ${ }^{34}$. Podobnie jak w przypadku drukarń, przejęcie zakładów papierniczych pod tymczasowy zarząd państwowy było ich nacjonalizacją. W przypadku przemysłu papierniczego decyzja ta miała szczególną wagę, bowiem umożliwiła komunistom sprawowanie nad nim pełnej kontroli, a przecież po wojnie papier miał ogromne znaczenie jako główny nośnik informacji. Henryk Golański, podsekretarz stanu w Ministerstwie Przemysłu, w latach 1945-1950 odpowiedzialny za koordynowanie prac Centralnych Zarządów Przemysłu: Włókienniczego, Papierniczego, Skórzanego, Budowlanego i Drzewnego, mówił o tym ex post (w 1980 r.): „W toczącej się walce klasowej papier mógł być - i bywał - orężem propagandy i agitacji, orężem politycznym. Mówiliśmy zatem otwarcie odpowiedzialnym pracownikom przemysłu papierniczego: produkujecie broń, bądźcie więc czujni. Macie klucze od arsenału. Strzeżcie ich pilnie"35.

${ }^{30}$ AAN, CUWPGiK, 10, k. nlb., Uwagi przemysłu graficznego dotyczące właściwości papierów drukarskich [listopad 1955 r.].

${ }_{31}$ Zarządzenie Biura Ekonomicznego przy Prezydium PKWN z 5 grudnia 1944 r. wydane w porozumieniu z Kierownikiem Resortu Informacji i Propagandy o zajęciu papieru na rzecz państwa. „Dziennik Świadczeń Rzeczowych”, 1944, nr 3, poz. 11.

${ }^{32}$ Instytucje wydawnicze realizujące interesy komunistów otrzymywały papier po cenach ,sztywnych" i bez procedur biurokratycznych. Pozostałych wydawców obowiązywała cena ,wolnorynkowa” oraz składanie podań, rozliczeń, planów wydawniczych z podaniem każdego tytułu oraz ilości i klasy papieru. MIiP wyznaczało także drukarnię. Jego działalność kolidowała z gospodarką papierem prowadzoną przez Centralny Urząd Planowania oraz działaniami Ministerstwa Przemysłu, które w 1945 r. powołało Centralny Zarząd Przemysłu Papierniczego. W efekcie w 1946 r. gospodarowanie papierem powierzono CUP oraz CZPP - zob. S. A. Kondek, dz. cyt., s. 56-65.

${ }^{33}$ Dekret PKWN z dnia 30 października 1944 r. o ochronie państwa, Dz. U., 1944, nr 10, poz. 50.

${ }^{34}$ M. Szymczyk, Polski przemyst papierniczy 1945-1989, Duszniki Zdrój 2007, s. 69-87.

${ }^{35}$ Henryk Golański, Poczatki polskiego papiernictwa powojennego, rozmowę przeprowadził Stefan Libiszowski, „Przegląd Papierniczy”, 3:1980, s. 91. 
Papier stał się towarem deficytowym w wyniku podjętych przez władze działań mających utrudnić dostęp do niego wydawcom niezależnym, jak i z powodu nieudolnego nim gospodarowania i przeznaczania przede wszystkim na druki propagandowe (zwłaszcza przy okazji kampanii politycznych przed referendum z 30 czerwca 1946 r. i wyborami z 19 stycznia 1947 r. - Ministerstwo Informacji i Propagandy w ciagu kilku miesięcy przed referendum wydrukowało 943 tys. plakatów, 32,3 mln ulotek, $1,1 \mathrm{mln}$ afiszy i odezw oraz $0,5 \mathrm{mln}$ sloganów, $10,7 \mathrm{mln}$ egz. broszur, co wskazuje na ogromne zużycie papieru i nieliczenie się z kosztami w sytuacji, gdy społeczeństwo liczyło $24 \mathrm{mln}$ obywateli, a kraj był biedny i wyniszczony wojną ${ }^{36}$ ).

Restrykcje odnośnie dostępu do papieru wprowadził dekret o gospodarce papierem z 1948 roku. Akt prawny wprowadzał za używanie do druku papieru bez wymaganego zezwolenia lub obrót papierem karę aresztu do trzech miesięcy i grzywnę do 300 tys. $z^{37}$. Jednak decydujący wpływ na to, czy dana książka mogła się ukazać i w jakim nakładzie, miały Główny Urząd Kontroli Prasy, Publikacji i Widowisk oraz Komisja do Spraw Papieru na Druk Książek, powołana przy Prezydium Rady Ministrów w lipcu 1947. Jak twierdził znawca problematyki, Stanisław Kondek, „manipulacje dostępem do papieru drukowego ukrywano odwołaniami do zasad «planowego gospodarowania». Jednak stosowane w praktyce zasady rozdzielnictwa służyły realizacji celu ideologicznopolitycznego bez nadmiernego liczenia się z jakąkolwiek racjonalnością gospodarczą"38.

Nieracjonalna gospodarka papierem doprowadziła m.in. do sytuacji takiej jak ta z 1952 r., kiedy po kontroli limitów Narodowego Banku Polskiego zapotrzebowanie na papier w wydawnictwach znacznie zmalało. Wydział Przydziału Papieru i Normalizacji CUWPGiK ustalił pulę zaopatrzenia $\mathrm{w}$ papier na wydawnictwa książkowe $\mathrm{i}$ akcydensowe na 1952 r. w oparciu o analizę wyników zużycia papieru w 1951 r. i powiększenie tej wielkości o ok. $15 \%$. Na tej podstawie zatwierdzono plany wydawnicze w pełnej wysokości wszystkim oficynom podległym urzędowi. Jednak po nadesłaniu zapotrzebowania na papier na I kwartał okazało się, że różniło się ono od ilości i gatunków planowanych. W II kwartale, po kontroli NBP (wypłacającego kredyty na działalność wydawnictw),

${ }^{36}$ Zob. Andrzej Krawczyk, Pierwsza próba indoktrynacji. Działalność Ministerstwa Informacji i Propagandy w latach 1944-1947, Warszawa 1994, s. 30, 35, 50.

${ }^{37}$ Dekret Rady Ministrów z dnia 26 kwietnia 1948 r. o gospodarce papierem, Dz. U., 1948, nr 24, poz. 163.

${ }^{38}$ S. A. Kondek, dz. cyt., s. 65. 
większość wydawnictw zrzekała się przydziałów, co spowodowało interwencję CZPP i Biura do Spraw Papieru, bo fabryki papieru - pozbawione zamówień - nie mogły z kolei wykonać swoich planów. Zapotrzebowania na III kwartał zmalały o ok. 63\%. w stosunku do planów, wydział zrzekł się więc części papieru drzewnego klasy VII i V z puli wydawnictw książkowych. W IV kwartale, w związku z zarządzeniem prezesa CUWPGiK o polepszeniu jakości wydawanych książek oraz zwiększeniu ilości książek w twardej oprawie, zapotrzebowanie na papiery bezdrzewne oraz tekturę było o wiele większe niż planowane. Jednocześnie fabryki papieru przestawiły produkcję na papier gazetowy ze względu na XIX Zjazd Wszechzwiązkowej Partii Komunistycznej (bolszewików; przemianowanej na zjeździe na Komunistyczną Partię Związku Radzieckiego) oraz wybory do Sejmu ${ }^{39}$.

Kwestia papieru, a właściwie jego braku, była niezwykle „paląca”. Prezes CUWPGiK wprowadzał coraz to nowe zarządzenia dotyczące oszczędnej gospodarki papierem, wydawnictwa poddawano kontroli pod tym kątem ${ }^{40}$. W 1954 r. wykryto na przykład, że „Czytelnik”, mimo nakazu pozbycia się wszystkich nadwyżek, magazynował papier na druk dzieł Mickiewicza (w 1955 r. obchodzono setną rocznicę śmierci poety). Wydawnictwo tłumaczyło się tym, że papier ten wyprodukowano kilka lat temu jednorazowo, bo tylko to mogło zapewnić jednakowy wygląd wszystkich tomów ${ }^{41}$. Urząd oczywiście o tym wiedział. Zresztą jedna z dyrektyw prezesa CUWPGiK zobowiązywała drukarzy do sortowania papieru przed drukiem, aby w jednym egzemplarzu książki stosowano jeden gatunek papieru, bowiem różnorodność w zakresie odcieni barwy, gatunku i klasy była bardzo częsta ${ }^{42}$. W październiku 1955 r. CUWPGiK wydał zarządzenie, które miało zmobilizować załogi fabryk papierniczych do stałej poprawy jakości produkowanego materiału. Zalecił mia-

${ }^{39}$ AAN, CUWPGiK, 2, s. 196-197, Sprawozdanie z działalności Samodzielnego Wydziału Przydziału Papieru i Normalizacji za okres od 1 stycznia do 31 października $1952 \mathrm{r}$.

${ }^{40}$ Tylko od października 1951 do grudnia 1952 r. prezes CUWPGiK wydał siedem zarządzeń i pism okólnych w sprawie gospodarki papierem. AAN, CUWPGiK, 34, s. 15, Skorowidz zarządzeń i pism okólnych...; AAN, Państwowa Komisja Planowania Gospodarczego, 6128, k. nlb., Pismo Państwowej Komisji Planowania Gospodarczego do Prezesa Karola Kuryluka z 8 marca 1955 r. w sprawie gospodarki papierem; tamże, Protokół nr PI-WA-3612-312-CZ/54 z kontroli gospodarki materiałowej przeprowadzonej w Centralnym Zarządzie Wydawnictw w Warszawie ul. Jasna 26 od 21.12.1954 r. do 7.01.1955 r.

${ }^{41}$ AAN, CUWPGiK, 8. Protokół z 17 listopada 1954 do prezesa CUWPGiK Karola Kuryluka w sprawie kontroli w „Czytelniku” odnośnie gospodarki papierem.

${ }_{42}$ AAN, CUWPGiK, 4, k. nlb., Protokół nr 11 z posiedzenia Kolegium CUWPGiK z 14 października 1953. 
nowicie zamieszczanie w metryczce książek nazwy fabryki papieru ${ }^{43}$. Z tego samego powodu od 1953 r. w kolofonie wpisywane było nazwisko redaktora odpowiedzialnego, a następnie - w ramach ,podnoszenia jakości opracowań" - pojawiły się nazwiska redaktora naukowego, technicznego oraz korektora ${ }^{44}$. Natomiast w 1953 r. urząd wprowadził zasadę, że do wszystkich książek wkładano kartki informujące czytelników o możliwości wymiany wybrakowanego egzemplarza w każdej księgarni „Domu Książki”. Z kolei wydawnictwo mogło obciążać w związku z tym finansowo drukarnie ${ }^{45}$.

Prezes CUWPGiK wydał w maju 1952 r. zarządzenie w sprawie podniesienia poziomu jakości szaty graficznej książek i zwiększenia ilości książek w trwałej oprawie ${ }^{46}$. Zgodnie z wytycznymi dyrektorzy wydawnictw mieli przy udziale fachowego personelu przeprowadzić kontrolę zaplanowanej szaty graficznej książek objętych planem wydawniczym na 1952 r. Oprócz tego zarządzenie zobowiązało tychże dyrektorów do zatwierdzania szaty graficznej na podstawie szczegółowego opisu, makiety, wzorów okładek i ilustracji. Prezes urzędu zezwolił nawet „Domowi Książki” na przekroczenie limitów o koszt opraw, ale tylko w uzasadnionych przypadkach.

Oprócz zarządzeń dotyczących poprawy jakości szaty graficznej CUWPGiK jednocześnie wydawał specjalne instrukcje odnośnie oszczędności w zużywaniu papieru na publikacje książkowe czy dozwolonych formatów lub polecenie zmian klas papieru i gramatur na niższe oraz wprowadzał do planów wydawniczych poszczególnych oficyn zalecenia w tej kwestii, co nie prowadziło w efekcie do podniesienia poziomu szaty graficznej. I tak np. „Iskrom” w I kwartale 1953 r. zezwolono na zamówienie papieru bezdrzewnego jedynie na wznowienie Bajek Ignacego Krasickiego i wkładki. Nakazano ograniczyć zapotrzebowanie na papier V klasy do $40 \%$ i przejście na papier klasy VII. Zastosowanie papieru lepszego gatunku możliwe było tylko w przypadku, gdy wymagała tego

${ }^{43}$ Obowiązek ten nie dotyczył książek, które drukowano na papierze pochodzącym z remanentów.. AAN, CUWPGiK, 30, s. 240, Zarządzenie Prezesa Centralnego Urzędu Wydawnictw, Przemysłu Graficznego i Księgarstwa nr 104 z dnia 11 października $1955 \mathrm{r}$. w sprawie zamieszczania w metryczce książki nazwy fabryki papieru.

${ }^{44}$ Zob. R. Tomaszewski, Jak Czytelnik podwyższa..., s. 8.

${ }^{45}$ AAN, CUWPGiK, 14, k. nlb., Uchwała nr 28 Kolegium Centralnego Urzędu Wydawnictw, Przemysłu Graficznego i Księgarstwa o zadaniach przemysłu poligraficznego na najbliższy okres 1953-1954 podjęta na posiedzeniu w dniu 6 października $1953 \mathrm{r}$. (prot. nr 10).

${ }^{46}$ AAN, CUWPGiK, 27, s. 124-126, Zarządzenie nr 47 Prezesa Centralnego Urzędu Wydawnictw, Przemysłu Graficznego i Księgarstwa z 14 maja 1952 r. w sprawie podniesienia poziomu jakości szaty graficznej książek i zwiększenia ilości książek oprawnych. 
technika druku ${ }^{47}$. W 1954 r. papier klasy III stanowił zaledwie 5\% ogólnego przydziału na produkcję książek ${ }^{48}$.

Kolejne zarządzenia, narady, komisje, zespoły, wskazania itp. mające przyczynić się do poprawy szaty graficznej niewiele zmieniały. CUWPGiK ,walczył” ze złym wyglądem publikacji cyklicznie od chwili swego powstania. W 1954 r. zaplanował po raz kolejny, że podniesiona zostanie jakość szaty graficznej książek, ale tym razem cel miał zostać osiagnięty poprzez stworzenie specjalnej komórki nadzoru artystycznego nad szatą graficzna, wystosowanie postulatów do Związku Polskich Artystów Plastyków i Ministra Kultury i Sztuki w sprawie odpowiedniego szkolenia grafików, tworzenie rad artystycznych przy wydawnictwach, a przy samym urzędzie - Rady Artystycznej, dla oceny projektów ważniejszych pozycji ${ }^{49}$.

Specjalna komisja CUWPGiK do spraw masowych serii literatury pięknej zajęła się ustalaniem szaty graficznej książek serii masowych różnych oficyn wydawniczych. Tak przedstawia się sformułowana przez zespół propozycja dla serii Nowa Biblioteka Trzyzłotowa: „format kolumny $82 \times 104$, druk garmond, okładka lakierowana ze ściętymi rogami, karta tytułowa $\mathrm{w}$ dwu-trzech kolorach, drut zastapiony szyciem, papier gazetowy w nieco lepszym gatunku, jak na ,Trybunę Ludu”, okładka jednolita dla całej serii wydawniczej oznaczona wyróżniającym serię symbolem" 50 .

Od 1955 r. prezes CUWPGiK wydawał cyklicznie specjalne zarządzenia dotyczące serii masowych przeznaczonych dla czytelnika wiejskiego. Wytyczne te obejmowały autorów, tytuły, wydawców, i drukarnie, nakład, szczegóły związane z drukiem oraz szatą graficzna. I tak dla serii Biblioteka Chłopskiej Drogi, Biblioteka Gromady i Biblioteka Przyjaciółki wyznaczono: druk na maszynach rotacyjnych, na papierze rolowym drukowym matowym kl. VI (przy czym tytuły „Chłopskiej Drogi”

${ }^{47}$ AAN, CUWPGiK, 26, s. 8. Zarządzenie nr 1 Prezesa Centralnego Urzędu Wydawnictw, Przemysłu Graficznego i Księgarstwa z 29 października 1951 r. w sprawie zmniejszenia zużycia papieru i zwiększenia oszczędności w miesiącach listopadzie i grudniu 1951 r.; tamże, 2, Protokoły Prezydium Centralnego Urzędu Wydawnictw, Przemysłu Graficznego i Księgarstwa. [Plany wydawnicze poszczególnych wydawnictw za I kwartał 1953 r.]; tamże, 38, s. 1-2. Instrukcja nr 2 Prezesa Centralnego Urzędu Wydawnictw, Przemysłu Graficznego i Księgarstwa z 9 marca 1953 r. w sprawie oszczędności w zużywaniu papieru na publikacje książkowe.

${ }^{48}$ AAN, CUWPGiK, 7, Protokół nr 5 z posiedzenia Kolegium Centralnego Urzędu Wydawnictw, Przemysłu Graficznego i Księgarstwa z 18 października 1954 r.

${ }^{49}$ AAN, CUWPGiK, 5, k. nlb., Protokół nr 5 z posiedzenia Kolegium Centralnego Urzędu Wydawnictw, Przemysłu Graficznego i Księgarstwa z 22 lutego 1955 r.

${ }_{50}$ AAN, CUWPGiK, 23, k. nlb. Protokół z posiedzenia komisji do spraw masowych serii literatury pięknej w planach wydawniczych na 1955 r. z 21 lipca 1954 r. 
i „Przyjaciółki” - na papierze o szer. 84 cm, „Gromady” - o szer. $63 \mathrm{~cm}$ ), szycie nićmi, oprawę w okładki z kartonu nie cieńszego niż 160 gr/mkw. Okładki drukowane w dwóch kolorach, przy czym układ graficzny książki i okładki każde wydawnictwo miało rozwiązać we własnym zakresie. Format kolumny: dla książek drukowanych na papierze szer. $84 \mathrm{~cm}$ - po obcięciu $130 \times 202 \mathrm{~mm}$, dla tych drukowanych na papierze o szer. $63 \mathrm{~cm}$ - format po ocięciu $157 \times 220 \mathrm{~mm}$. Wszystkie tytułu miały być złożone garamondem na cicerze, tj. 10/12 pkt. Cen nie należało drukować ani na okładce, ani w kolofonie ${ }^{51}$.

W następnym roku do wymienionych trzech serii doszła Złota Biblioteka - 18 tytułów w nakładach po 50 tys. egz. w okładkach jednolitych, $\mathrm{z}$ tłoczeniami złotą folią na grzbiecie, obwolutami utrzymanymi w jednolitym odcieniu żółtego, z ilustracjami, ale nie więcej niż strona na 1 arkusz wydawniczy, w formacie po obcięciu $148 \times 210 \mathrm{~mm}$, skład 12/14, szycie nićmi, tekturowe okładki obciągnięte ekrudą, bez wydrukowanych $\operatorname{cen}^{52}$.

Oprócz tego wśród serii masowych dla wsi były m.in. Biblioteka Rolnika i Co Miesiąc Broszura Rolnicza. CUWPGiK określał także ogólne wytyczne dla serii masowych (nakłady, klasę papieru, rodzaj oprawy i ceny) w zależności od rodzaju literatury ${ }^{53}$.

Urząd postanowił walczyć ze złą szatą graficzną także poprzez zezwolenie Centralnemu Zarządowi Księgarstwa na nieprzyjmowanie nakładu książki o złej szacie graficznej, połączone z odwołaniem się do komisji arbitrażowej, która mogła obniżyć cenę katalogową książki ${ }^{44}$.

W 1953 r. prezes CUWPGiK polecił przeprowadzenie szeregu narad aktywu związkowego i partyjnego oraz powołał specjalną komisję, której zadaniem miało być: ustalenie zasad współpracy między wydawnictwami a drukarniami, opracowanie jednolitego systemu ewidencji i obiegu dokumentacji w zakresie gospodarki papierem, kartonem i tektura, usta-

\footnotetext{
${ }^{51}$ AAN, CUWPGiK, 30, s. 97-99. Zarządzenie Prezesa Centralnego Urzędu Wydawnictw, Przemysłu Graficznego i Księgarstwa nr 36 z dnia 13 kwietnia 1955 r. w sprawie bibliotek masowych dla wsi w $1955 \mathrm{r}$.

${ }^{52}$ AAN, CUWPGiK, 30, s. 296. Zarządzenie Prezesa Centralnego Urzędu Wydawnictw, Przemysłu Graficznego i Księgarstwa nr 36 z dnia 6 grudnia 1955 ?r.? w sprawie bibliotek masowych dla wsi w $1956 \mathrm{r}$.

${ }^{53}$ AAN, CUWPGiK, 31, s. 13, Zarządzenie Prezesa Centralnego Urzędu Wydawnictw, Przemysłu Graficznego i Księgarstwa nr 11 z dnia 7 lutego 1956 w sprawie bibliotek masowych dla wsi.

${ }^{54}$ AAN, CUWPGiK, 23, k. nlb., Protokół z narady z 7 maja 1954 r.; tamże, s. 191 192. Zarządzenie Prezesa Centralnego Urzędu Wydawnictw, Przemysłu Graficznego i Księgarstwa [brak numeru] z dnia 29 czerwca 1955 r. w sprawie wydania poradników dla rolników.
} 
lenie skali formatów, klas, gatunków i gramatur papierów dla prac wydawniczych wszelkiego typu, sformułowanie zasad jakościowej kontroli otrzymywanych papierów ${ }^{55}$.

Wśród tez do referatu dyskusyjnego na naradę przedstawicieli wydawnictw i drukarń znalazły się zagadnienia jakości produkcji dotyczące wszelkiego rodzaju błędów:

1. Skład. Przeważającą część zdolności produkcyjnych zecerni pochłaniaja wydawnictwa naukowe i techniczne. Plany tych wydawnictw rosną bardzo poważnie i temu zagadnieniu należy poświęcić specjalną uwagę.

Główne wady składu wykonanego dla wydawnictw naukowych i technicznych:

1) Niewłaściwe wykonanie frakcji /występują b. często na jednej linii z pismem zasadniczym/.

2) Frakcje pomieszane /obce kroje/ np. a, g, w, v oraz zły krój czcionki alfa.

3) Znaki minusów we wzorach i frakcjach pomieszane z pauzami.

4) Cyfry frakcji w różnych krojach i wielkościach.

5) Wektory nad symbolami i daszki poprzesuwane/zawsze ręcznie justowane/.

6) Różne wielkości składu wykonane różnymi krojami pisma /np. petit Jonio, nonparel - Excelsior/.

7) Brak dostatecznej ilości krojów czcionek tytułowych.

8) Drukarnie nie posiadają wzorników czcionek.

9) Niska jakość składu /słaba korekta domowa/.

10) Niestaranne poprawianie korekt.

11) Złe justowanie układu ręcznego.

Rezultat. Tysiące godzin zmarnowane na poprawianie. Błędy w książkach /powyrywane czcionki/, co odbija się ujemnie na wyglądzie estetycznym książki i wymaga dodatkowych korekt. Zjawisko to powoduje wydłużenie cyklu produkcyjnego.

Przyczyny. Bałagan w kasztach i podręcznych magazynach linotypowych. Olbrzymie braki w zaopatrzeniu /nie widać żadnej dbałości o zaopatrzenie ani jakiegoś metodycznego rozeznania w brakach i usunięcia ich/.

${ }^{55}$ AAN, CUWPGiK, 34, s. 53, Pismo okólne nr 22 Prezesa Centralnego Urzędu Wydawnictw, Przemysłu Graficznego i Księgarstwa z dnia 8 grudnia 1953 r. w sprawie gospodarki papierem; tamże, 28, s. 151-154, Zarządzenie nr 83 Prezesa Centralnego Urzędu Wydawnictw, Przemysłu Graficznego i Księgarstwa z 23 listopada w sprawie gospodarki papierem do druku. 
2. Druk. Zdolność produkcyjna hal maszyn jest w dużej mierze wykorzystywana dla wydawnictw literatury pięknej i młodzieżowej. Trzeba stwierdzić, że im większe są nakłady książek, tym jakość ich druku jest niższa.

Główne wady druku:

1) Nierówne tłoczenie.

2) Nierówne krycie farbą.

3) Zabrudzenia, plamy i zamazania arkuszy.

4) Skandaliczny druk klisz siatkowych.

5) Wiersze niedotłoczone i przetłoczone.

6) Niestaranne dobranie kolorów /szary odcień farby/.

Rezultat. Część produkcji wydawnictw jest wykonana na niezłym poziomie poligraficznym, czasem bardzo dobrym, co świadczy, iż zakłady są w stanie dać dobrą produkcję. Jednakże przeważająca część produkcji jest wykonana na bardzo niskim poziomie. Niektóre partie tekstu sa nieczytelne. W wydawnictwach matematycznych wiele form i wzorów nie do odcyfrowania. Klisze siatkowe w przeważającej części to jedna szara plama. Okładki i druki kolorowe bardzo często rażąco odbiegają od oryginału. Są pozycje, których wypuszczenie na rynek nie powinno mieć miejsca.

Przyczyny. Źle, niestarannie wykonane wycinki. Charakterystyczne, że wydania na papierach ilustracyjnych III kl., za których narząd i druk zakłady stosują większe stawki, są wykonane gorzej jak na papierach zwykłych /klisze siatkowe/. Nieprzypilnowanie nakładu podczas druku / specjalnie przy dużych nakładach/. Zły dobór kolorów. Bardzo niska jakość farb. Zła jakość składu /wiersze źle justowane, wiersze za niskie i za wysokie/. Źle wykonane klisze.

3. Oprawa. Oprawy nasze zarówno broszurowe, jak i sztywne pozostawiają bardzo wiele do życzenia. Okładka to wizytówka książki.

Od jej wyglądu często zależy chodliwość książki.

Główne wady oprawy:

1) Nierówno obciagane zakładki.

2) Pofałdowane grzbiety.

3) Zwijanie się okładek sztywnych.

4) Fatalne tłoczenia.

5) Krzywe obcinanie bloków ${ }^{56}$.

\footnotetext{
${ }^{56}$ AAN, CUWPGiK, 57, k. nlb. Podaję za: D. Jarosz, dz. cyt., s. 40-41.
} 
Oprawy twarde wprowadzano do produkcji masowej stopniowo od 1952 roku, kiedy to ukazało się ok. 2,6 mln egz. książek w twardej oprawie. W 1953 r. miało ich być już 7 mln egzemplarzy, co stanowiło jednak mniej niż 10\% z planowanych 75 mln egz. w ogóle. W 1954 r. miał nastapić wzrost opraw twardych o $100 \%$ - do $14 \mathrm{mln}$ egz. Było to trudne do osiagnięcia m.in. z następujących powodów:

1) park maszynowy do oprawy książek w dużych zakładach nie jest w pełni wykorzystany,

2) w żadnym $z$ zakładów nie oprawia się $w$ systemie potokowym,

3) braki w wykwalifikowanych pracownikach ${ }^{57}$.

Stałym problemem była także zła jakość materiałów introligatorskich. Drukarnie otrzymywały niekalibrowaną tekturę (różnej grubości), która uniemożliwiała oprawę maszynową. Fabryki włókiennicze w Łodzi, Bielawie i Walimiu nie mogły poradzić sobie z produkcją odpowiedniej jakości płócien introligatorskich ${ }^{58}$. Nie pomagały wspólne konferencje w Centrali Tekstylnej w Łodzi, podczas których dokładnie omawiano wymagania co do płócien i innych materiałów introligatorskich ${ }^{59}$.

Na słaba jakość druków wpływała także zła jakość farb (szczególnie czarnej). Nie pomagały interwencje w Ministerstwie Przemysłu Chemicznego ${ }^{60}$. Farby produkowane były wprawdzie według tych samych receptur co w NRD, ale miały gorszą jakość, bowiem używano np. innej sadzy czy oleju lnianego ${ }^{61}$. Poza tym stosowanie farb odbywało się przeważnie w sposób zupełnie dowolny, bez uwzględnienia charakteru druku i formy, jak również papieru ${ }^{62}$.

Sześcioletni plan rozwoju gospodarczego i budowy podstaw socjalizmu na lata 1950-1955 przewidywał m.in. dwukrotne zwiększenie produkcji poligraficznej. Rzeczywiste uwarunkowania: baza techniczna w złym stanie, brak odpowiednich kadr technicznych (nieodpowiedni system kształcenia i szkoleń) oraz powiązań z nauką (w postaci własnego

${ }^{57} \mathrm{R}$. Tomaszewski, Czy mamy odpowiednie warunki do produkcji masowych sztywnych opraw? „Poligrafika”, 4:1953, s. 13.

${ }_{58}$ Zob. R. Tomaszewski, O niektórych zagadnieniach masowych opraw ksiażek, „Poligrafika”, 5:1952, s. 7-9.

${ }^{59}$ AAN, CUWPGiK, 18, k. nlb., Protokół z konferencji z 18.10.1952 r. w Centrali Tekstylnej w Łodzi w sprawie płótna introligatorskiego na rok 1953.

${ }^{60}$ AAN, CUWPGiK, 2, k. nlb., Protokół nr 25 z posiedzenia Prezydium C.U.W. odbytego w dniu 11 sierpnia $1952 \mathrm{r}$.

${ }^{61}$ AAN, CUWPGiK, 7, k. nlb., Protokół nr 58 Kolegium Centralnego Urzędu Wydawnictw, Przemysłu Graficznego i Księgarstwa z 15 października 1954 r.

${ }^{62}$ Zob. J. Karolczak, Zagadnienie kontroli technicznej w przemyśle graficznym, „Poligrafika", 5:1952, s. 5. 
instytutu badawczego i kadr naukowych), a przede wszystkim system zetatyzowanej gospodarki centralnie planowanej, której podlegały wydawnictwa i przemysł graficzny, powodowały, że jakość produkcji wydawniczej, szczególnie tej masowej, była niska. Nadmiernie zbiurokratyzowany CUWPGiK, nadzorujący w latach 1951-1965 rynek wydawniczy, nie panował nad podległymi sobie jednostkami. Jego działania na rzecz poprawy poziomu szaty graficznej i wykonania książek polegały głównie na kolejnych przekształceniach organizacyjnych i wydawaniu nowych zarządzeń. Na fali zmian roku $1956^{63}$ urząd został wcielony do Ministerstwa Kultury i Sztuki i przekształcony w Departament Wydawnictw. Problem jakości szaty graficznej i wykonania ksiazżek nie został całkowicie rozwiązany i pojawiał się do zmian ustrojowych w $1989 \mathrm{r}$.

\section{Streszczenie}

\section{Problemy złej jakości wykonania książek w latach pięćdziesiątych XX wieku w Polsce: stalinowskie diagnozy, rzeczywiste przyczyny}

Na przełomie lat 40. i 50. XX w. książki wydawane masowo miały niską jakość szaty graficznej oraz wykonania. Władze tłumaczyły, że ten stan rzeczy wynika z wadliwego i przestarzałego systemu planowania produkcji poligraficznej i wydawniczej. W rzeczywistości najważniejszymi przyczynami złej jakości produkcji wydawniczej były: przestarzały park maszyn poligraficznych, ubogie wyposażenie drukarń w materiał zecerski, brak odpowiednich kadr technicznych i naukowych oraz nienajwyższy gatunek materiałów: papieru, farby drukarskiej, artykułów introligatorskich.

Działania władz na rzecz poprawy poziomu szaty graficznej i wykonania książek polegały głównie na kolejnych przekształceniach organizacyjnych i wydawaniu nowych zarządzeń. Problem jakości szaty graficznej i wykonania książek nie został rozwiązany do zmian ustrojowych w $1989 \mathrm{r}$.

${ }^{63}$ W 1956 r. do władzy doszła nowa ekipa działaczy partyjnych z Władysławem Gomułką na czele, która w początkowym okresie wprowadziła zmiany liberalizujące ówczesny system władzy. 


\section{Summary}

\section{Quality Problems with Book Production in Poland of the Nineteen-Fifties: Stalinist Diagnoses and Real Causes}

Books published in mass issues at the break of the nineteen-forties and the nineteen-fifties were characterised by low quality of production and graphic design. The communist authorities explained this state of affairs with faulty, obsolete planning methods of production and publishing. Actually, the main causes for the low quality of book production lay in technical problems with old and worn out machinery, inadequate supply of typeset matter, poor quality of materials (paper, ink, binding cardboard and cloth), and lack of qualified personnel.

Nevertheless, the communist authorities limited their activities aimed at changing this situation chiefly to endless restructuring of the managing and planning institutions, and to issuing of new directives. Thus, problems with the quality of the graphical side of books and their physical state persisted until the change of the political and economic system in 1989. 